\title{
Genetic diversity in Egeria densa and E. najas in Jupiá Reservoir, Brazil
}

\section{Edson S. Mori ${ }^{1}$, Dagoberto Martins ${ }^{1}$, Edivaldo D. Velini ${ }^{1}$, Celso L. Marino ${ }^{2}$, Cantídio F. Gouvêa ${ }^{3}$, Suzi M.M. Leite ${ }^{2}$, Edwin Camacho ${ }^{1}$, and Raymond P. Guries $^{4}$}

${ }^{1}$ Departamento de Produção Vegetal, Faculdade de Ciências Agronômicas, Universidade Estadual Paulista Júlio de Mesquita Filho - Rua Dr. José Barbosa de Barros, 1780 - CEP18610-307 - Botucatu, SP, Brazil. ${ }^{2}$ Departamento de Genética, Instituto de Biociências, Universidade Estadual Paulista Júlio de Mesquita

Filho - Distrito de Rubião Junior, S/N - CEP 18618-970 - Botucatu, SP, - Brazil.

${ }^{3}$ Departamento de Ciências Florestais, Universidade Federal de Sergipe - Av. Marechal Rondon, s/n, Jardim Rosa Elze - CEP 49100-000 - São Cristóvão,SE, Brazil.

${ }^{4}$ Department of Forest and Wildlife Ecology, University of Wisconsin - Madison - 1630 Linden Dr., Madison, WI 53706, USA.

\begin{abstract}
E.S. Mori, D. Martins, E.D. Velini, C.L. Marino, C.F. Gouvêa, S.M.M. Leite, E. Camacho Palomino, and R.P. Guries. 2012. Genetic diversity in Egeria densa and E. najas in Jupiá Reservoir, Brazil. Cien. Inv. Agr. 39(2):321-330. The aquatic plant species Egeria densa (Planch.) Casp and E. najas Planchon occur naturally in the Paraná River Basin of southeastern Brazil. Hydroelectric dam construction in the river basin has created several lakes, changing the ecology of the river and altering the population ecology of Egeria. Large, dense populations of Egeria now grow in Jupiá Lake and its tributaries, occasionally blocking hydroelectric turbines. This study is part of a larger project examining environmental changes associated with large dam projects; the research objective of this study was to assess patterns of genetic diversity in Egeria populations growing in Jupiá and Três Irmãos Lakes and their Paraná River tributaries using genetic markers. Forty-two plants of E. najas and 46 of $E$. densa (for a total of 88 samples) were collected from 13 sites. Genotypes were identified by isoenzymes and Random Amplification of Polymorphic DNA RAPD markers. Using a genetic distance dendrogram we grouped all $E$. densa plants into one set and all E. najas plants into another set. The plant sample 8a, which presented intermediary morphological characteristics of both species, also presented intermediary genetic characteristics, indicating the possibility that gene introgression between these Egeria species may occur. The creation of Três Irmãos Lake appears to have increased some measures of genetic diversity in Egeria populations by facilitating outcrossing among previously semiisolated genotypes. Increased migration of large numbers of seeds and vegetative branches of $E$. densa and E. najas into Jupiá Lake and its tributaries can account for most of the changes in patterning of genetic diversity observed in these populations of Egeria.
\end{abstract}

Key words: Egeria, dam, isoenzyme, genetic distance, RAPD, reservoir.

\section{Introduction}

The Paraná River Basin drains an enormous landscape covering parts of Brazil, Argentina, Paraguay and Uruguay before emptying into the

Received May 10, 2011. Accepted October 5, 2011. Corresponding author: esmori@fca.unesp.br
South Atlantic near Buenos Aires, Argentina. Several hydroelectric dams constructed since 1950 have created large reservoirs on the Paraná River, including the $35 \mathrm{sq}$. km Jupiá Lake, thereby altering the natural ecology of this formerly free flowing river. Some aquatic plants, such as the native species Egeria densa (Planch.) Casp and E. najas Planchon (both Hydrocaritaceae), 
previously restricted to riverine margins and pools, have multiplied rapidly in Jupiá Lake and become 'nuisance' plants (Getsinger and Dillon, 1984; Haramoto and Ikusima, 1988; Mori et al., 1999; Oliveira et al., 2005; Martins et al.,2009).

During the rainy season, enormous quantities of Egeria branches block turbines at the 1400 Kwatt capacity Jupiá hydroelectric facility, with damage and maintenance costs estimated at approximately 1.5 million dollars (Melloni, 1998). Other Hydrocaritaceae, such as Lagarosiphon major (Bowmer et al., 1995; Lambertini et al., 2010), Hydrilla verticilatta (Bowmer et al., 1995; Les et al., 1997), Ipomoea aquatica Forsk (Van and Madeira, 1998), Elodea canadensis and E. densa (Lambertini et al., 2010) are well-known exotics that have become serious pests in rivers and lakes in the southern United States and western counties in Oregon (Carter and Sytsma, 2001).

Many types of aquatic weeds have caused tremendous damage in lakes, rivers, and irrigation drains throughout the world (Moody et al., 2008). These weeds include the following species: Egeria spp. (Martins et al., 2003), Typha subulata (Prates et al., 1996), and Eichhornia azurea (Ikusima and Gentil, 1993) in Brazil; Patamogeton illinoensis (Bezic et al., 1996; Armellina et al., 1996) in Argentina; E. canadensis (Bowmer et al., 1984), Vallisneria Americana var. americana Michaux (Roberts et al., 2001; Robert et al., 1999) in Australia; and Paspalum distichum (Shibayama, 1988) in Japan.

E. densa is an aquatic plant that is able to grow in heavy metal contaminated and polluted bodies of water (Malec et al., 2009), multiplying rapidly in polluted lakes.

Ryan et al. (1995) and Les et al. (1997) found low DNA polymorphism in $H$. verticillata in lakes within the USA. Similarly, Pieterse et al. (1984) found low polymorphism using isoenzymes to examine lake populations in Ireland and Poland, as did Ryan (1988) in USA lakes.
In a study on dioecious and monoecious biotypes of Hydrilla that occur in the United States, Madeira et al. (2004) described an alternative molecular tool using a polymerase chain reaction (PCR) to discriminate monoecious from dioecious plants.

E. densa and E. najas species became a problem in Jupiá Lake only when Três Irmãos Lake was constructed on the Tietê River, which enters the Paraná River just upriver from Jupiá Lake, Brazil. To create the Três Irmãos Lake, the Tietê River was diverted for six months, giving E. densa and E. najas populations an opportunity to cover the then-empty Tietê River channel between Jupiá and Três Irmãos Lakes (Mori et al., 1999).

The dams supply ideal conditions for E. najas populations to multiply and invade new areas via asexual reproduction (Mori et al., 1999; Carvalho et al., 2003). They verified vegetative growth of E. najas from plant fragments of $5 \mathrm{~cm}$. Therefore, the hydroelectric turbines have contributed to the spread of E. najas by breaking up plants during the energy production process.

Both E. densa and E. najas are submerged, perennial dioecious plants that grow best at water temperatures between 15 and $25^{\circ} \mathrm{C}$. Reproduction is largely asexual via branches that can survive and grow without roots anchored in soil. Reproduction by seed is rare, and it is unusual to find both sexes growing side by side, making pollination by insects difficult (Cook and Urmi-Kbnig, 1984; Kissmann 1991).

No prior information is available on genetic diversity in E. densa or E. najas, but both are morphologically very similar to Hydrilla verticilata (L. F.) Royle, a species that has been the subject of isoenzyme and DNA analyses (Aulback-Smith, 1990). In addition, Verkleij et al. (1983) studied 28 populations of $H$. verticilata from Pakistan, India, Malaysia, Indonesia, New Zealand, USA, Panama and Poland, using 18 isoenzymatic systems. Les et al. (1997) and Ryan et al. (1995) characterized $H$. verticilata using molecular markers. 
Power companies and facility managers find it difficult to believe that previously 'well-behaved' species such as Egeria could change their ecology so dramatically following dam construction, and they question whether other changes are responsible. Examining the current patterns of genetic diversity in Jupiá Lake might suggest whether major genetic change has recently occurred; such knowledge might be useful in predicting future environmental change. The objective of this research was to examine the current genetic diversity in E. densa and E. najas populations in Jupiá Lake and tributaries of Paraná River using molecular markers. This study is part of a larger project examining the environmental effects of dam construction.

\section{Materials and methods}

\section{Plant materials}

The map presented in Figure 1 shows the distribution of the thirteen plant sample sites throughout the Jupiá Reservoir, Tietê River, Pereira Barreto Canal, and São José dos Dourados River, Brazil.

The stems of E. densa and E. najas are monomorphic, elongate, up to $3 \mathrm{~m}$ or more in length, and irregularly branched; branches are borne at "double internodes", resembling the main stem. Their leaves are opposites or whorled without stipules and are not differentiated into petiole and lamina (Cook and Urmi-Ko"nig, 1984). Reproduction is largely asexual via branches that can survive and grow without roots anchored in soil. Reproduction by seed is rare, and it is unusual to find both sexes growing side by side, making pollination by insects difficult (Kissmann, 1991).

Thirteen sites were selected for sampling. Some sites did not have populations of both Egeria species, thus a different number of samples were collected per site. A site along the Sucurí River was originally included in the sampling design but no Egeria plants were found in this location.

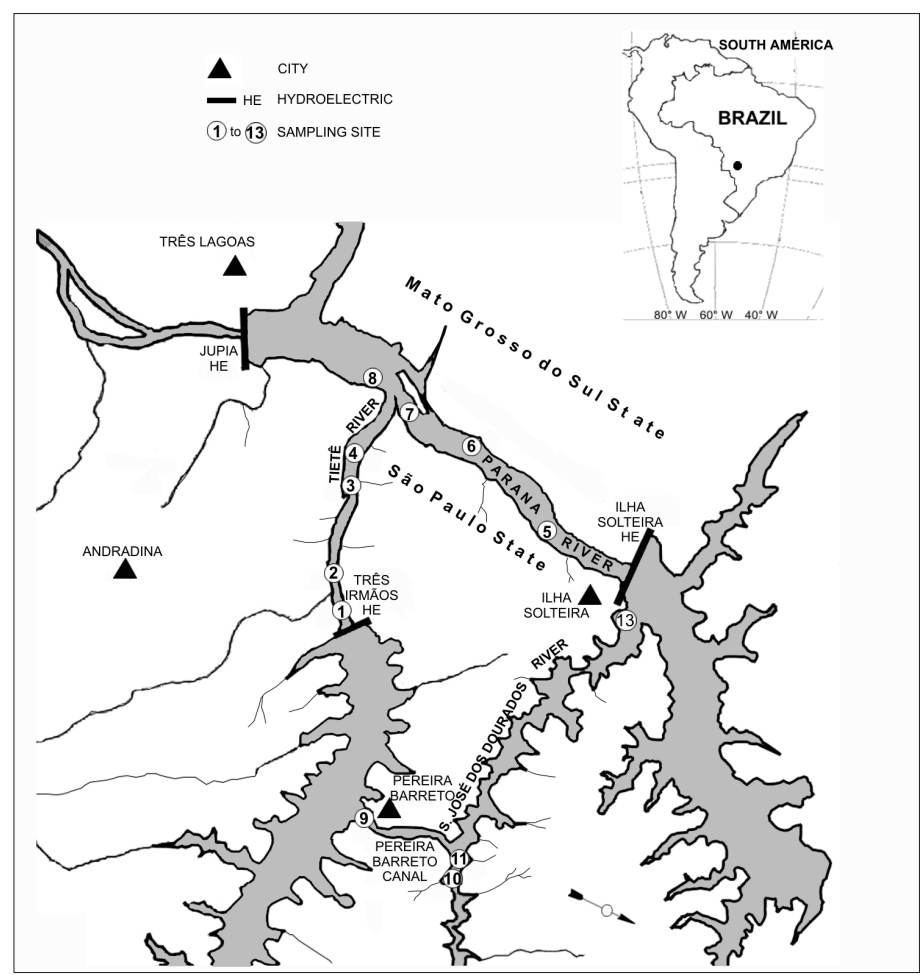

Figure 1. Map showing the sites where Egeria densa and E. najas are distributed in Jupiá Reservoir, Tietê River, Pereira Barretos Canal, and São José dos Dourados River, Brazil. 


\section{Specimen collection}

The original sampling design called for collecting plants of both species from seven sub-populations at each of 13 sites (a total of 91 sub-populations for each species) along Jupiá Lake, the Tietê, Sucurí and São José dos Dourados Rivers, and Pereira Barreto Canal, along the border between the States of São Paulo and Mato Grosso do Sul, Brazil (Table 1). In approximately half of the sites, one or the other Egeria species was absent from a sub-population (Table 2); a total of 88 plants were collected for the two species (42 E. najas plants and 46 E. densa plants).

Collections from Egeria sub-populations were separated by a distance of at least $200 \mathrm{~m}$. Plant specimens were transferred to an aquarium at the Department of Crop Science, São Paulo State University (UNESP), Botucatu, SP, Brazil. Species identities were confirmed morphologically, and live plants were maintained in the aquarium to provide easy access to specimens for DNA and isoenzyme extractions.

\section{Isoenzyme procedures}

Isoenzymes are widely used as molecular markers to understand the genetic relationships within and among populations. Relative to other types of molecular markers (e.g., RAPDs or RFLPs), isoenzymes are relatively inexpensive for population survey work, have a well-established genetic function, and can be conducted with a minimum of sophisticated, expensive electrophoresis equipment (Hedrick, 1971; Rogers, 1972; Nei, 1978; and Wain et al., 1985). The technique used in this study involved minor variations from frequently cited methods. One hundred milligram of fresh leaves from each plant were used to prepare a crude homogenate using the extraction technique of Verkleij (1983). Three gel/electrode buffer systems (Figure 2) were used based on Cheliak and Pitel (1984), Alfenas et al. (1991) and Ballve et al. (1991), with electrophoresis performed at temperatures near $5{ }^{\circ} \mathrm{C}$. A total of 17 isoenzymatic systems were studied, including AAT, ACP, ADH, CAT, $\alpha$-EST, $\beta$-EST, GDH, G6P, G2D, IDH, LAP, MADH, MDH, ME, PEX, SDH, and

Table 1. Branch collection sites and sample numbers from locations along Jupiá Lake, Tietê River, Pereira Barreto Canal, and São José dos Dourados River, Brazil.

\begin{tabular}{|c|c|c|c|}
\hline Species & Site & Collection Site & \# of Sub-Sample per Collection Site \\
\hline \multirow[t]{6}{*}{ Egeria densa } & Tietê River & Ed1 & 1(1) to $1(7)$ \\
\hline & & Ed2 & $2(1)$ to $2(7)$ \\
\hline & & Ed3 & $3(1)$ to $3(7)$ \\
\hline & & Ed4 & $4(1)$ to $4(7)$ \\
\hline & Jupiá Lake & Ed5 & $5(1)$ to $5(7)$ \\
\hline & & Ed7 & $7(1)$ to $7(7)$ \\
\hline \multirow[t]{14}{*}{ Egeria najas } & Tietê River & En1a & $1(4)$ \\
\hline & & En1b & $1(7)$ \\
\hline & & En2 & $2(6)$ \\
\hline & & En4 & $4(5)$ \\
\hline & Jupiá Lake & En5 & $5(1)$ and from $5(2)$ to $5(7)$ \\
\hline & & En6 & $6(1)$ to $6(7)$ \\
\hline & & En7 & $7(1)$ to $7(4)$ and $7(7)$ \\
\hline & & $8 \mathrm{a}$ & $8(1)$ \\
\hline & & En8b & $8(2)$ \\
\hline & Pereira Barreto Canal & En9 & $9(1)$ to $9(7)$ \\
\hline & S. J. Dourados River & En10 & $10(1)$ \\
\hline & & En11 & $11(1)$ to $11(7)$ \\
\hline & & En12 & $12(1)$ to $12(7)$ \\
\hline & & En13 & $12(1)$ \\
\hline Total & & & 88 plants \\
\hline
\end{tabular}

Note: E.g.: \# of Sub-Samples per Collection Site - 13(1) means Sub-Sample 1 of Site En13. 
SKDH (Cheliak and Pitel; 1984; Yamada and Guries, 1989).

\section{RAPD procedures}

As a comparison to the isoenzyme analysis described above, a sub-sample of plants were also analyzed using Random Amplified Polymorphic DNA (RAPDs) according to the procedure of Williams et al. (1990), modified by Grattapaglia and Sederof (1994).

DNA was extracted from $150 \mathrm{mg}$ of leaves ground in $700 \mu 1$ of CTAB buffer $[100 \mathrm{mM}$ of Tris-HC ( $\mathrm{pH} 8.0), 1 \%$ hexadecyltrimethylammonium bromide (CTAB), $0.7 \mathrm{M} \mathrm{NaCl}, 10 \mathrm{mM}$ EDTA, $2 \%$ mercaptoethanol and $1 \%$ polyvinylpirimidine (PVP)] and heated to $65^{\circ} \mathrm{C}$ for 30 to 60 minutes with shaking. This solution was added to 600 $\mu \mathrm{L}$ of chloroform-isoamylic alcohol (24:1 v/v); tubes were shaken gently and then centrifuged at $6,000 \mathrm{rpm}$ for 15 minutes. The homogenate was then emulsified again in CTAB buffer, the supernatant was added to 0.5 volume of $5 \mathrm{M}$ $\mathrm{NaCl}$ and 2 volumes of isopropanol at $-20{ }^{\circ} \mathrm{C}$, and the tubes were shaken gently until DNA precipitated. Following incubation at $-20{ }^{\circ} \mathrm{C}$ for approximately 12 hours, the solution was centrifuged at 3,000 rpm for 3 minutes. The DNA pellets were washed with ethanol, dried at room temperature and re-dissolved in TE buffer with RNAse $(1 \mu \mathrm{L}$ per $100 \mu \mathrm{L}$ of DNA) for 2 hours at $37^{\circ} \mathrm{C}$. The relative amount of DNA for each sample was quantified and stored at $-20^{\circ} \mathrm{C}$.

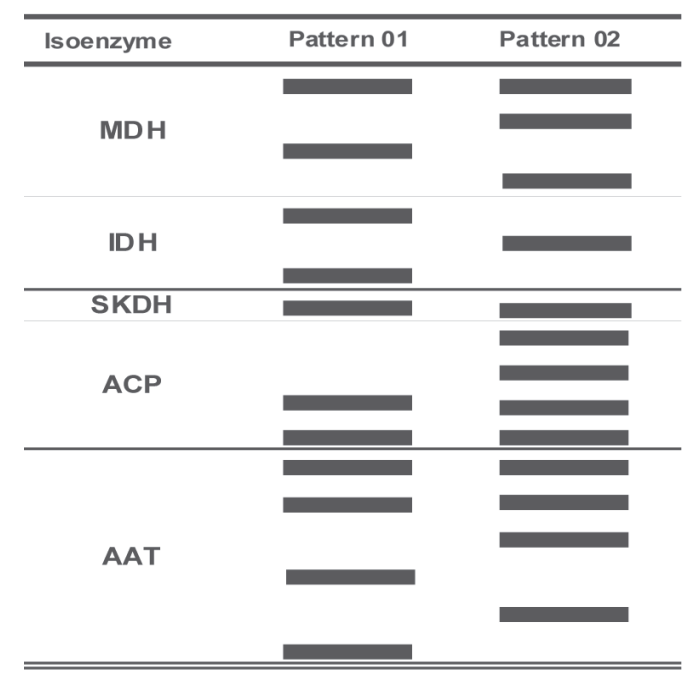

Figure 2. Banding patterns of the five isoenzyme systems of Egeria densa and E. najas.

Fifty 10-mer primers were tested using an Operon kit; six polymorphic primers were selected for further use in this study. The sequences are as follows: P-01 - GTAGCACTCC, P-16 - CCAAGCTGCC, P-17 - TGACCCGCCT, J-01 - CCCGGCATAA, J-11 - ACTCCTGCGA, and J-17 - ACGCCAGTTC.

Each analysis was performed in a $13 \mu$ reaction containing $10 \mathrm{mM}$ Tri-HCl pH 8.3, $50 \mathrm{mM} \mathrm{KCl}, 1.5$ $\mathrm{mM} \mathrm{MgCl}, 0.1 \%$ Triton-X, $200 \mathrm{mM}$ for each dNTP, $0.4 \mathrm{mM}$ of each primer, $0.01 \mathrm{mg}$ non-acetylated bovine serum albumin, 5 to $10 \mathrm{mg}$ genomic DNA and 1 unit of Taq polymerase (Promega). The reactions were overlaid with $50 \mu \mathrm{L}$ of mineral oil. The amplification reaction included an initial denaturation step of 1 minute at $92^{\circ} \mathrm{C}$, followed by 40 cycles of 1 minute at $35^{\circ} \mathrm{C}$ and 2 minutes at $72^{\circ} \mathrm{C}$.

Table 2. The isoenzyme phenotypes identified for each sub-population collection site for Egeria densa and E. najas.

\begin{tabular}{|c|c|c|c|c|c|c|}
\hline \multirow[b]{2}{*}{ Collection Site } & \multirow[b]{2}{*}{ Species } & \multicolumn{5}{|c|}{ Phenotype } \\
\hline & & $\mathrm{MDH}$ & IDH & SKD & $\mathrm{ACP}$ & AAT \\
\hline $\mathrm{Ed} 1, \mathrm{Ed} 2, \mathrm{Ed} 3, \mathrm{Ed} 4, \mathrm{Ed} 5$, and Ed7 & Egeria densa & 1 & 1 & 1 & 1 & 1 \\
\hline $8 \mathrm{a}$ & $?$ & 2 & 2 & 1 & 2 & 2 \\
\hline En8b & & 1 & 1 & 1 & 1 & 1 \\
\hline En1 & Egeria najas & 1 & 1 & 1 & 2 & 2 \\
\hline En4 and En7 & & 1 & 2 & 1 & 2 & 2 \\
\hline En2, En5, En6, En9, En10, En11, and En12 & & 2 & 2 & 1 & 2 & 2 \\
\hline
\end{tabular}




\section{Genetic analysis}

We used the unweighted pair group method with arithmetic averages (UPGMA) algorithm cluster analysis to construct genetic dendrograms using the 75 polymorphic RAPD bands and 19 polymorphic isoenzyme bands ( 94 bands in total) amplified in each of the 88 individuals.

\section{Result}

Only five of the 17 isoenzyme systems studied were polymorphic: MDH, IDH, SKD, ACP, and AAT. Two distinct phenotypes were found for each of these five systems (Figure 2), with five distinct clusters of sub-populations. All E. densa plants were included in one group, while E. najas was divided into 4 groups (Table 2).

Six of the fifty 10 -mer primers tested were polymorphic in one or more sub-populations of both E. densa and E. najas (Figure 3). Some primers revealed more polymorphisms than others.

A dendrogram constructed using RAPD data cleanly separates the two species without mixing sub-populations or plants. The dendrogram in Figure 3 was built using estimates of Nei's genetic identity between $E$. densa and E. najas.
The sample $8 \mathrm{a}$, which showed intermediary morphological characteristics, lay midway between both species in the dendrogram, thus confirming that the sample also has intermediate genetic characteristics.

\section{Discussion}

In reservoirs and in large, slow-moving rivers, Egeria colonies can multiply to high densities and occupy large areas. Where water flow is rapid, there are typically only a few or no Egeria plants growing on the river floor. However, in the channel of the Tietê River, between Jupiá and Três Irmãos Lakes, large, dense populations of both species now occur.

The results of this study revealed that all 42 individuals of $E$. densa from six different collection sites throughout the Tietê River and Jupiá Lake are identical at isoenzymatic loci. Based upon isoenzyme data alone, we might conclude that a single clone of $E$. densa now occupies the entire study area. E. najas populations were slightly more polymorphic and appear to form four groups (Table 2). Similarly, Verkleij et al. (1983) reported that all US populations of the exotic plant, $H$. verticilata, sampled in their study had identical isoenzyme phenotypes.

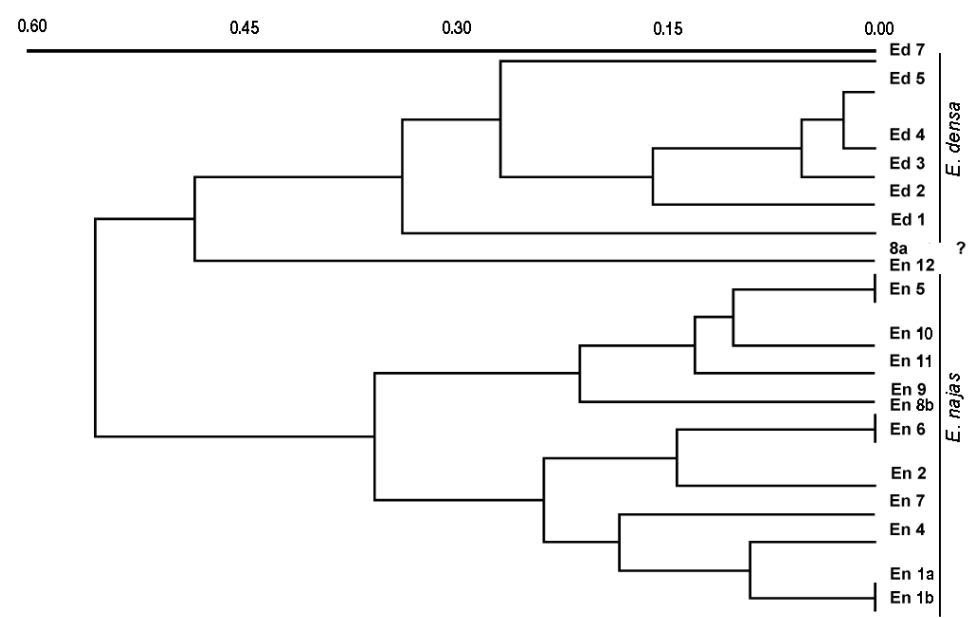

Figure 3. Genetic distance dendrogram of Egeria najas and E. densa based on Nei's (1978). 
The authors concluded that the vast Hydrilla populations in US lakes appear to share a single clonal origin most likely arising from a single colonization event.

The limited amount of polymorphism present in the isoenzyme systems studied in Egeria spp. cannot provide answers to most questions concerning population differences.

Within each species, almost all sub-populations appear closely related, with genetic distance coefficients higher than 0.25 . However, there are a few plants that appear less typical of the species, with coefficients of genetic distance from 0.25 to 0.50 . For example, based on morphological characteristics, plant 8a appears to be E. najas, but may share some RAPD patterns common to E. densa. We have no independent evidence that inter-specific hybridization or introgression is occurring between both Egeria species, but the coexistence of these plants in mixed populations, and the modified environment of the rivers and lake, make hybridization a possibility that should be examined more closely.

Most E. najas samples collected in the Pereira Barretos Canal and the São José dos Dourados River appeared very similar genetically (genetic distance coefficient $>0.25$ ), but only plants collected at site En12 (São José dos Dourados River and Pereira Barretos Canal) and at site En5 (Jupiá Lake) were identical for all RAPD and isoenzyme markers. These results indicate that the canal facilitates the transfer and spread of single genotypes of $E$. najas from the Tietê River via Pereira Barretos Canal into Jupiá Lake or via the Paraná River into Jupiá Lake.
At the En1 site, we collected two ramets of $E$. najas of the same genotype in two different subsamples at $800 \mathrm{~m}$ distance, indicating that large single clonal populations may also exist.

The genetic diversity in the Egeria populations observed in Jupiá Lake and its tributary rivers may have originated from different populations in the Paraná River Basin through either sexual or asexual reproduction. The prevalence of sexual reproduction in $E$. densa was modest at best, similar to levels of sexual reproduction observed in E. najas (Mori et al., 1999), suggesting that the major source of new diversity in Jupiá Lake is the introduction of vegetative shoots. This pattern of colonization by one or a few well-adapted genotypes is consistent with observations of other aquatic perennials such as $H$. verticilata (Verkleij et al., 1983), Elodea nuttalli (Kodono et al., 1997), and E. najas (Mori et al., 1999; Martins et al., 2003).

In natural environments, male and female plants of E. densa may be separated by hundreds of meters, so pollination is not frequent (Cook and Urmi-Kbnig, 1984). However, the new environmental conditions created in Jupiá Lake following dam construction, e.g., more and larger sub-populations, may actually facilitate outcrossing in Egeria and provide more opportunities for interspecific hybridization.

\section{Acknowledgments}

The authors thank CESP Company, FAPESP, and FUNDUNESP Foundations for sponsorship of the study, and the engineers and staff of CESP Company who supported field activities. 


\section{Resumen}

E.S. Mori, D. Martins, E.D. Velini, C.L. Marino, C.F. Gouvêa, S.M.M. Leite, E. Camacho Palomino y R.P. Guries. 2012. Diversidad genética en plantas acuáticas de Egeria densa y $\boldsymbol{E}$. najas en el lago de Jupiá. Cien. Inv. Agr. 39(2):321-330. Las especies acuáticas de Egeria densa y E. najas ocurren naturalmente en la Cuenca del Río Paraná, sudeste del Brasil. La construcción de una represa hidroeléctrica en la cuenca de este río, creó varios lagos, cambiando la ecología del río y alterando la populación ecológica de Egeria. Grandes y densas poblaciones de Egeria crecen hoy en día en el lago de Jupiá y sus afluentes, bloqueando de vez en cuando las turbinas de la hidroeléctrica. Como parte de un estudio de cambios ambientales, asociados a grandes proyectos de represas, fueron usados marcadores moleculares para determinar patrones de diversidad genética en las poblaciones de Egeria que crecen en los lagos de Jupiá, Três Irmãos y sus afluentes del Río Paraná. En un total de 13 sitios, fueran colectadas 42 plantas de E. najas y 46 de $E$. densa, que suman un total de 88 muestras. Los genotipos fueron identificados por marcadores de isoenzimas y RAPD. A través de dendrogramas de distancia genética se agruparon por separado todas las plantas de E. densa y de E. najas. La muestra 8a presentó plantas con características morfológicas e genéticas intermediarias de ambas las especies, indicando haber posibilidades de introgresión de genes entre ambas las especies de Egeria. La creación del lago de Três Irmãos parece haber aumentado, en alguna medida, la diversidad genética de las populaciones de Egeria por la facilidad de cruzamientos entre genotipos, hasta entonces semi-aislados. La migración creciente de grandes cantidades de semillas y de partes vegetativas de Egeria densa y Egeria najas dentro del Lago Jupiá y sus afluentes, pueden explicar los cambios observados en los patrones de diversidad genética en estas populaciones de Egeria.

Palabras clave: Egeria, distancia genética, isoenzima, RAPD, represa.

\section{References}

Alfenas, A.C., I. Peters, and W. Brune. 1991. Eletroforese de proteínas e isoenzimas de fungos e essências florestais. Vicosa. 242 pp.

Armellina, A.D., C.R. Bezic, O.A. Gajardo, and A. Dall'Armellina. 1996. Propagation and mechanical control of Potamogeton illinoensis Morong in irrigation canals in Argentina. J. Aquat. Plant Manage. 34: 12-16.

Aulback-Smith, C.A. 1990. Aquatic and wetland plants of South Carolina. South Carolina Aquatic Plant Management Counsil. Columbia, S.C. 123 pp.

Ballve, R.M., R. Bordignon., H.P. Medina Filho., W.F. Siqueira., J. Teófilo Sobrinho, and J. Pompeu Jr. 1991. Isoenzimas na identificação precoce de híbridos nucelares no melhoramento de citros. Bragantia, Campinas 50: 57-76.

Bezic, C., A. Dall'Armellina, O. Gajardo, J.M. Caffrey, P.R.F. Barret, K.J. Murphy, and M. Wade. 1996. Studies of vegetative propagation of Pota- mogeton illinoensis Morong in southern Argentina. Hydrobiologia 340: 7-10.

Bowmer, K.H., D.S. Mitchell, and D.L. Short. 1984. Biology of Elodea canadensis Mich. And its management in Australian irrigation systems. Aquatic Botany 18: 231-238.

Bowmer, K.H., S.W.L. Jacobs, and G.R. Sainty. 1995. Identification, biology and management of Elodea canadensis, Hydrocharitaceae. J. Aquat. Plant Manage. 33: 13-19.

Carter, M.C., and M.D. Sytsma. 2001. Comparison of the genetic structure of North and South American populations of a clonal aquatic plant. Biological Invasions 3: 113-118.

Carvalho, F.T., E.D. Velini, E.F. Frazzatto, F.M. Anjos, and M. Peruchi. 2003. Análise temporal do crescimento vegetativo de Egeria najas a partir de fragmentos da planta. Planta daninha 21: 101-104.

Cheliak, W.M., and J.A. Pitel. 1984. Techniques for starch gel electrophoresis of enzymes from forest tree species. Patawawa National Foresty 
Institute, Canadian Foresty Service Information Report PI - X - 42.49 pp.

Cook, C.D.K., and K. Urmi-Kbnig. 1984. A revision of the genus Egeria (Hydrocharitaceae). Aquat. Bot. 19: 73-96.

Getsinger, K.D., and C.R. Dillon. 1984. Quiescence, growth and senescence of Egeria densa in Lake Marion. Aquat. Bot. 20: 329-338.

Grattapaglia, D., and R. Sederoff. 1994. Genetic linkage maps of Eucalyptus grandis and Eucalyptus urophylla using a pseudo-testcross: mapping strategy and RAPD markers. Genetics 137: 1121-1137.

Haramoto, T., and I. Ikusima. 1988. Life cycle of Egeria densa Planch., an aquatic plant naturalized in Japan. Aquat. Bot. 30: 389-403.

Hedrick, P.W. 1971. A new approach to measuring genetic similarity. Evolution 25: 276-280.

Ikusima, I., and J.G. Gentil. 1993. Vegetative growth and productivity of Eichhornia azurea with special emphasis on leaf dynamics. Ecological Research 8: 287-295.

Kissmann, K.G. 1991. Plantas infestantes e nocivas. Tomo I. Edit. Basf. p. 226-229.

Kadono Y, T. Nakamura, and T. Suzuki. 1997. Genetic uniformity of two aquatic plants, Egeria densa Planch. and Elodea nuttallii (Planch.) St. John, introduced in Japan. Jpn J. Limnol. 58: 197-203.

Lambertini, C., T. Riis, B. Olesen, J.S. Clayton, B.K. Sorrell, and H. Brix. 2010. Genetic diversity in three invasive clonal aquatic species in New Zealand. BMC Genetics 11: 2-18.

Les, D.H., L.J. Mehrhoff, M.A. Cleland, and J.D. Gabel. 1997. Hydrilla verticillata (Hydrocharitaceae) in Connecticut. J. Aquat. Plant Manage. 35: 10-14.

Madeira, P.T., T.K. Van, D. Ted, and T.D. Center. 2004. An improved molecular tool for distinguishing monoecious and dioecious Hydrilla. J. Aquat. Plant Manage. 42: 28-31.

Malec, P., M.G. Maleva, M.N.V. Prasad, and K. Strzalka. 2009. Identification and characterization of Cd-induced peptides in Egeria densa (water weed): Putative role in Cd detoxification. Aquatic Toxicology 95: 213-221.

Martins, D., L.R. Cardoso, E.S. Mori, and R.H. Tanaka. 2003. Caracterização genética de acessos de egéria (Egeria spp.) coletados no estado de São Paulo utilizando RAPD. Planta Daninha 21:1-6.

Martins, D., R.A. Pitelli, M.S. Tomazella, R.H. Tanaka, and A.C.P. Rodrigues. 2009. Levantamento da infestação de plantas aquáticas em Porto Primavera antes do enchimento final do reservatório. Planta Daninha, Viçosa-MG 27: 879-886.

Melloni, E. 1998. Planta afeta produção de Hidrelétrica de Jupiá. O Estado de São Paulo, São Paulo. 09 jul. 1998. Folha A14, p. 1.

Moody, M.L., D.H. Les, and J.M. Ditomaso. 2008. The role of plant systematics in invasive aquatic plant management. J. Aquat. Plant Manage. 4:7-15.

Mori, E.S., C.F. Gouvêa, S.M.M. Leite, C.L. Marino, D. Martins, and E.D. Velini. 1999. Caracterização genética de populações de Egeria najas presentes no reservatório de Jupiá e rios aluentes. Planta Daninha 17: 217-225.

Nei, M. 1978. Estimation of average heterozygosity and genetic distance from a small number of individuals. Genetics 89: 583-589.

Oliveira, N.M.B, E.V.S.B. Sampaio, S.M.B. Pereira, and A.M. Moura Junior. 2005. Capacidade de regeneração de Egeria densa nos reservatórios de Paulo Afonso, BA. Planta Daninha, Viçosa-MG 23: 363-369.

Pieterse, A.H., A.E.H. Ebbers, and J.A.C. Verkleij. 1984. A comparative study on isoenzyme patterns in Hydrilla verticilata ( $\mathrm{L}>\mathrm{F}>$ ) Royle from Ireland and Noth Eastern Poland. Aquatic Botany 18: 299-303.

Prates, H.T., J.B. Silva, J.D. Fabris, G.A.L. Ferreira, C.E.P. Leite, and M.J. Batista. 1996. Curva de dissipação de Imazapyr em água de drenos de irrigação, após a aplicação para controle da taboa. Planta Daninha 14: 127- 133.

Roberts, D.E., A.G. Church, and S.P. Cummins. 1999. Invasion of Egeria into the hawkesburynepean river, Australia. J. Aquat. Plant Manage. 37: 31-34.

Roberts, D.E., G.R. Sainty, S.P. Cummins, G.J. Hunter, and W.J. Anderson. 2001. Managing submersed aquatic plants in the Sydney International 
Regatta Centre, Australia. J. Aquat. Plant Manage. 39: 12-17.

Rogers, J.S. 1972. Measures of genetic similarity and genetic distance. University Texas Publ. 7213: 145-153.

Ryan, F.J. 1988. Partial characterization of a major family of proteins in turions of Hydrilla verticillata. Physiology Plantarum 73: 486-493.

Ryan, F.J., C.R. Coley, and S.H. Kay. 1995. Coexistence of monoecious and dioecious Hydrilla verticillata in Lake Gaston, North Carolina and Virginia. J. Aquat. Plant Manage. 33: 08-12.

Shibayama, H. 1988. Ecology of aquatic weeds in creeks of the paddy growing area in the lower reaches of the Chikugo river. Bulletin of the Kyushu National Agricultural Experiment Station 25: 01-75.

Van, T.K., and P.T. Madeira. 1998. Random amplified polymorphic DNA analysis of Water Spin- ach (Ipomoea aquatica) in Florida. J. Aquat. Plant Manage. 36: 107-111.

Verkleij, J.A.C. 1983. A comparative study of the morphology and isoenzyme patterns of Hydrilla verticillata (L. f.) Royle. Aquatic Botany 17: 4359.

Wain, R.P., W.T. Haller, and Martin, D.F. 1985. Isozyme in studies of aquatic plants. J. Aquat. Plant Manage. 23: 42-45.

Williams, J.G.K., A.E. Kubelik, K.J. Livac, J.A. Rafalski, and S.C.D. Tingey. 1990. DNA polymorphisms amplified by arbitrary primers are useful as genetic markers. Nucleic Acids Res. 18: 65316535.

Yamada, M.M, and R.P. Guries. 1989. A manual for starch gel electrophoresis. New Chocolate Lovers Edition. Staff Paper Series n.39. Department of Forestry. University of Wisconsin - Madison. 22 pp. 